\title{
Chemotherapeutic Activity of Polyhalogenated Terpenes from Spanish Algae ${ }^{1}$
}

\author{
A. G. González, V. Darias and E. Estévez
}

Instituto de Productos Naturales Orgánicos, CSIC, La Laguna Departamento de Farmacognosia y Farmacodinamia, Universidad de La Laguna, Tenerife, Canary Islands, Spain

\section{Key Word Index:}

Algae; Polyhalogenated Terpenes; Cytostatic and Antibacterial Activity.

\section{Abstract}

A study of the cytostatic and antibacterial activity of four halogenated alicyclic monoterpenes obtained from Plocamium cartilagineum $\mathrm{L}$. and of six polyhalogenated sesquiterpenes isolated from two species of Laurencia; L. obtusa Huds. and L. caespitosa LAmx. is presented. The first monoterpene series was proved to possess higher cytostatic activity. This greater inhibitory activity would seem to be related to a greater presence of halogens in the molecule.

The antibacterial activity of both series may be considered as noticeable although the sesquiterpene compounds isolated from the genus Laurencia proved more active in the tests reported here.

POLYHALOGENATED MONOTERPENES FROM PLOCAMIUM CARTILAGINEUM<smiles>C[C@]1(Br)CC(Cl)(Cl)[C@@H](Br)CC1/C=C/Cl</smiles><smiles>CC=CC1(C)[C@H](C)C(Cl)(Cl)[C@H](Cl)C[C@H]1C</smiles>

$P_{1}-D$
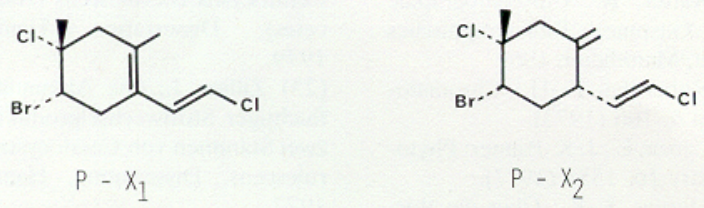

1 A report on this work was presented at the International Research Congress on Natural Products as Medicinal Agents. Strasbourg. July, 1980.
POLYHALOGENATED SESQUITERPENES FROM LAURENCIA CAESPITOSA AND L. OBTUSA

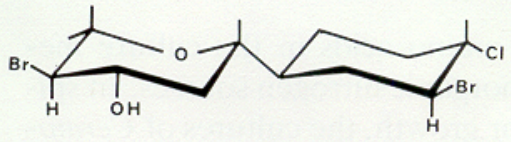

CAESPITOL

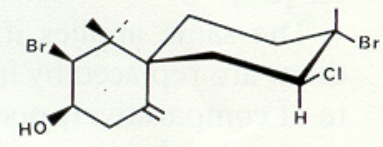

OBTUSOL

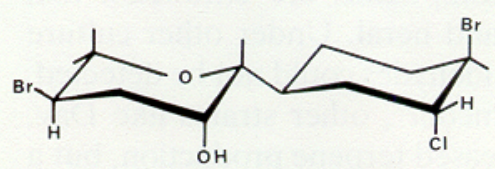

ISOCAESPITOL

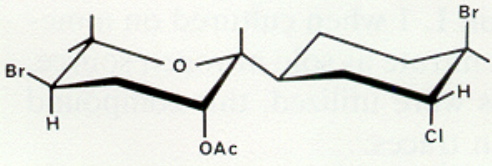

ISOCAESPITOL ACETATE

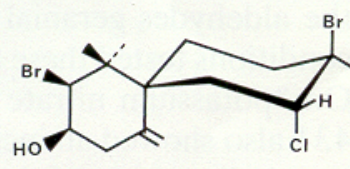

ISOOBTUSOL

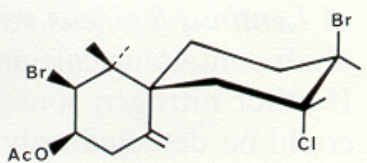

ISOOBTUSOL ACETATE

\section{Introduction}

Numerous symposia, congresses, scientific papers, reviews and books are a testimony to the growing importance of chemical and pharmacological research into marine natural products $[1,5]$. Despite intense work on the part of investigators devoted to the different taxonomic, ecological, chemical and pharmacological aspects of this field, its possibilities are, as yet, unpredictable. Convinced of the importance of the subject and compelled by geographical circumstances, the Institute of Organic Natural Products of the C. S. I. C. at the University of La Laguna established, some ten years ago, a line of investigation directed towards a deeper knowledge of the chemo-biological possibilities of the benthonic flora of Spain. 
In this paper we present a chemotherapeutic study of the major components of three species of Rhodophyceae found in abundance in the inter-tidal zones of the Spanish coasts.

\section{Material and Methods}

a) Plocamium cartilagineum (L.), gathered on the Playa de la Victoria, Cadiz, in June 1978, classified by Prof. J. SEOANE of the Faculty of Pharmacy, University of Barcelona and from which were extracted four new halogenated alicyclic monoterpenes, represented in Fig. 1, the structures of which were established by spectroscopic methods and by chemical transformation and were confirmed by $\mathrm{x}$-ray diffraction studies [6]. Compound $\mathrm{P}_{1}-\mathrm{B}$ proved to be a bromine analogue of an identical chloro-compound isolated from Plocamium violaceum [7].

b) Two species of the genus Laurencia: L. obtusa (Huds.) (LAMOUROUX) and L. caespitosa (LAMX.), both collected in September 1978 along the north coast of Tenerife and identified by the Department of Botany of the University of La Laguna. From these algae, four new polyhalogenated sesquiterpenes $[5,6,8$ and 9$]$ were mostly isolated, the structures of which were established by the above-mentioned methods $[8,9]$ and are represented in Fig. 2. It should be noted that the acetylated derivatives [7] and [10] were isolated, in high yield, from the digestive gland of the sea-hare, Aplysia dactylomela, an opisthobranch mollusc very frequently found in the zone and which feeds on this type of algae, confirming the works of IRIE et al. [10].

\section{Measurement of cytostatic activity}

The cytostatic activity was determined by measuring the inhibition of development of a single-layer culture of HeLa 229 cells in Difco's "TC minimal medium eagle dried" according to the method described by GERAN et al. [11]. The products tested were suspended in TWEEN 80 and a blank control and 6-mercapto purine as positive control were employed under identical conditions. The measurements of the tests were carried out after $72 \mathrm{~h}$ of incubation.

\section{Measurement of antibacterial activity}

The method used to determine antibacterial activity was that of CHABBERT [12], which, briefly, consists in seeding the different organisms over previously sterilised Agar Muller-Hilton $3.5 \%$ medium and observing the zones of growth inhibition around discs of WHATMAN no. 1 paper impregnated with different concentrations of the compounds to be tested. These concentrations were $0.25,0.51$ and 5 $\mathrm{mg} / \mathrm{ml}$. The measurement of results was taken after $24 \mathrm{~h}$ of incubation at $37^{\circ} \mathrm{C}$.

\section{Results and Discussion}

The results obtained for cytostatic activity are set out in Table I, together with the yields of the tested compounds. This data suggests that the monoterpenes from Plocamium cartilagineum present an interesting inhibitory activity with $\mathrm{ID}_{50}=1-10 \mu \mathrm{g} / \mathrm{ml}$, values inferior to or near those recommended by the protocols of the $\mathrm{Na}$ tional Cancer Institute of U.S.A. [11] to be followed by more sophisticated experiments.

The series under study being limited, it is difficult to establish any structure-activity relationship, although it may be deduced that greater richness in $\mathrm{Br}$ induces a greater cytostatic activity. We are experimenting at present with these products $\left(\mathrm{P}_{1}-\mathrm{B}\right.$ and $\left.\mathrm{P}_{1}-\mathrm{D}\right)$ on several types of murine tumours in order to evaluate their possibilities on systems "in vivo."

\section{Table I}

Cytostatic Activity on $\mathrm{He} \mathrm{La} \mathrm{Cells}$

A Monoterpenes from Plocamium Cartilagineum

\begin{tabular}{llllc}
\hline Compound & Molecular Formula & Yield $(\%) * \begin{array}{l}\mathrm{ID}_{50} \\
(\mu \mathrm{g} / \mathrm{ml})\end{array}$ \\
\hline 1 & $\mathrm{P}_{1}-\mathrm{B}$ & $\mathrm{C}_{10} \mathrm{H}_{14} \mathrm{Br}_{2} \mathrm{Cl}_{2}$ & 0.01 & 1 \\
2 & $\mathrm{P}_{1}-\mathrm{D}$ & $\mathrm{C}_{10} \mathrm{H}_{14} \mathrm{Br}_{2} \mathrm{Cl}_{2}$ & 0.008 & 1 \\
3 & $\mathrm{P}-\mathrm{X}_{1}$ & $\mathrm{C}_{10} \mathrm{H}_{13} \mathrm{BrCl}_{2}$ & 0.001 & 10 \\
4 & $\mathrm{P}-\mathrm{X}_{2}$ & $\mathrm{C}_{10} \mathrm{H}_{13} \mathrm{BrCl}_{2}$ & 0.001 & 10
\end{tabular}

B Sesquiterpenes from Laurencia Obtusa - L. Caespitosa

$\begin{array}{rlllc}5 & \text { Caespitol } & \mathrm{C}_{15} \mathrm{H}_{24} \mathrm{O}_{2} \mathrm{Br}_{2} \mathrm{Cl} & 0.03 & 100 \\ 6 & \text { Isocaespitol } & \mathrm{C}_{15} \mathrm{H}_{24} \mathrm{O}_{2} \mathrm{Br}_{2} \mathrm{Cl} & 0.06 & 50 \\ 7 & \text { Isocaespitol } & & & \\ & \text { Acetate } & \mathrm{C}_{17} \mathrm{H}_{26} \mathrm{O}_{3} \mathrm{Br} \mathrm{Br}_{2} \mathrm{Cl} & -* * & 10 \\ 8 & \text { Obtusol } & \mathrm{C}_{15} \mathrm{H}_{23} \mathrm{OBBr}_{2} \mathrm{Cl} & 0.02 & 50 \\ 9 & \text { Isoobtusol } & \mathrm{C}_{15} \mathrm{H}_{23} \mathrm{OBr}_{2} \mathrm{Cl} & 0.03 & 10 \\ 10 & \text { Isoobtusol Acetate } & \mathrm{C}_{17} \mathrm{O}_{25} \mathrm{O}_{2} \mathrm{Br}_{2} \mathrm{Cl} & -* * & 4.5 \\ & \text {-6 Mercapto } & & & \\ & \text { Purine- } & - & - & 0.1\end{array}$

* Referring to dry alga
* From digestive gland of APLYSIA DACTYLOMELA

\section{Table II}

Antimicrobial Testing of Monoterpenes from

Plocamium Cartilagineum

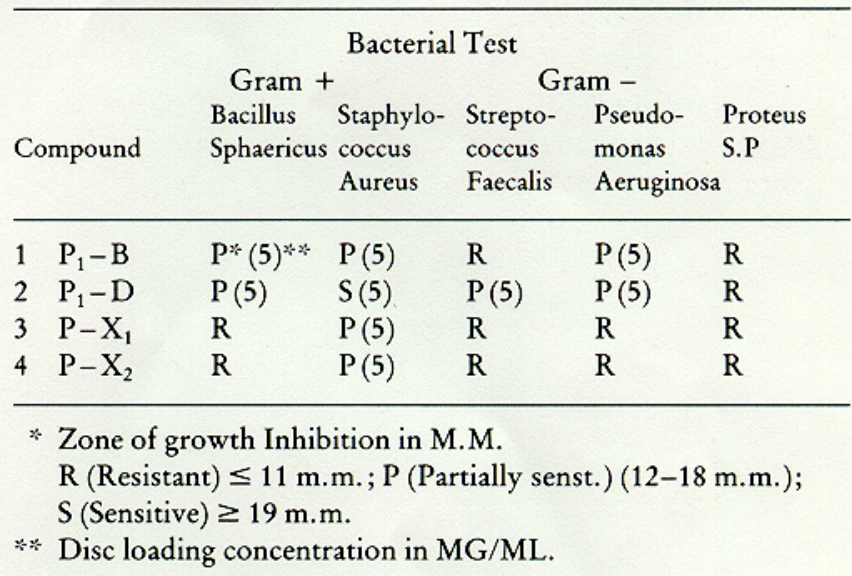

The polyhalogenated chamigrene-skeleton sesquiterpenes from species of Laurencia proved to be less active with ID $_{50}=(10-100 \mu \mathrm{g} / \mathrm{ml})$, with the exception of the isoobtusol acetate $\left(\mathrm{ID}_{50}=4.5\right)$. In this series, it may be deduced, firstly, that the acetylation of the hydroxyl group increases cytotoxicity and, secondly, that the compounds with halogens in trans are slightly more active than their corresponding cis isomers.

The results obtained on both Gram + and Gram bacteria are shown in Tables II and III. Activity may 


\section{Table III}

Antimicrobial Testing of Sesquiterpenes from Laurencia Caespitosa and L. Obtusa

\begin{tabular}{|c|c|c|c|c|c|c|}
\hline \multicolumn{2}{|c|}{ Compound } & \multirow{2}{*}{$\begin{array}{l}\text { Bacillus } \\
\text { Sphaericus }\end{array}$} & $\begin{array}{l}\text { Bacteria } \\
\text { Staphylo- } \\
\text { coccus } \\
\text { Aureus }\end{array}$ & $\begin{array}{l}1 \text { Test } \\
\text { Strepto- } \\
\text { coccus } \\
\text { Faecalis }\end{array}$ & $\begin{array}{l}\text { Pseudo- } \\
\text { monas } \\
\text { Aeruginosa }\end{array}$ & $\begin{array}{l}\text { Proteus } \\
\text { Sp. }\end{array}$ \\
\hline 5 & Caespitol & & $P(5)$ & $\mathbf{R}$ & $P(5)$ & $\mathrm{R}$ \\
\hline 6 & Isocaespitol & $\mathrm{lP}(5)$ & $P(1)$ & $\mathrm{R}$ & $S(5)$ & $\mathbf{R}$ \\
\hline \multirow[t]{2}{*}{7} & Isocaespitol & & & & & \\
\hline & Acetate & $P(1)$ & $\mathrm{S}(0.5)$ & $P(5)$ & $P(5)$ & $P(5)$ \\
\hline 8 & Obtusol & $P(5)$ & $P(5)$ & $P(5)$ & $P(5)$ & $\mathrm{R}$ \\
\hline 9 & Isoobtusol & $P(5)$ & $P(1)$ & $P(5)$ & $P(1)$ & $\mathrm{R}$ \\
\hline & Isoobtusol & & & & & \\
\hline & Acetate & $P(5)$ & $S(0.5)$ & $P(5)$ & $P(1)$ & $P(5)$ \\
\hline
\end{tabular}

globally be classified as noticeable, since those compounds isolated from Plocamium cartilagineum are only partially active at the highest dose tested $(5 \mathrm{mg} / \mathrm{ml})$ and singling out, if one must, a greater effectiveness against Staphylococcus aureus. The sesquiterpenes obtained from the genus Laurencia proved more active, pointing out once more both acetylated derivatives (compounds 7 and 10) against which the five organisms tested proved, at least partly, to be sensitive.

\section{Acknowledgements}

This investigation was financed by a grant from the Assessorial Commission of Scientific and Technical Research of Spain. We thank Ms. Emilia BAYO for her efficient and skillful technical work.

\section{References}

(1) González, A. G., J. Darias, J. D. Martín, V. S. Martín, M. Norte and C. Pérez: Marine Natural Products from the Atlantic Zone series, Tetrahedron Letters 2I, 1151 (1980). (2) Hoppe, H. A., T. Levring and Y. Tanaka: Marine Natural Products, Berlin 1979, Walter de Gruyer.

(3) Kaul, P. N.: Food and Drugs from the Sea, Norman 1978, The University of Oklahoma Press.

(4) Scheuer, P. J.: Marine Natural Products: Chemical and Biological Perspectives New York, 1978, Academic Press Inc.

(5) Webber, H. H. and G. D. Ruggieri: Proceeding of the Fourth Food-Drugs from the Sea Conference, Washington 1976, Marine Technological Society.

(6) González, A. G., J. M. Arteaga,
J. D. Martín, M. L. Rodríguez, J Fayos and M. Martínez-Ripoll: Phytochemistry, 17, 947 (1978).

(7) Mynderse, J. S. et al.: Tetrahedron Letters 2175 (1975).

(8) González, A. G., J. D. Martín, V. S. Martín, M. Martínez-Ripoll and J. Fayos: Tetrahedron Letters 29, 2717 (1978).

(9) González, A. G., J. Darias, J. D. Martín, C. Pérez, J. J. Sims, G. H. Y. Lin and R. M. Wing: Tetrahedron 31,2449 (1975).

(10) Irie, T. et al.: Bull. Chem. Soc. Japan 42,843 (1969).

(1I) Geran, R. I. et al.: Cancer Chemotherp. Rep. 332 (1972).

(12) Chabbert, Y. A.: Microbiología e Inmunología de las Enfermedades Infecciosas, Madrid, 1976, Ed. Marban.

Address: Dr. V. Darias del Castillo, I.P.N.O. del C.S.I.C., Carretera de la Esperanza 2, La Laguna, Tenerife, Canary Islands, Spain. 